Int Arch Allergy Immunol 1997;112:I-IV

\title{
Contents, Vol. 112, 1997
}

\section{No. 1}

Case Reports

\section{Editorial}

1 'Valediction'

Wick, G. (Innsbruck)

Mini Reviews

93

96

Morphea after Silicone Gel Breast Implantation for Cosmetic Reasons in an HLA-B8, DR3Positive Woman

Di Lorenzo, G.; Mansueto, P.; Melluso, M.; Barbagallo Sangiorgi, G.; Cigna, D.; Candore, G.; Caruso, C. (Palermo)

Transient CD80 Expression Defect in a Patient with Variable Immunodeficiency and Cyclic Neutropenia

Moser, C; Schlesier, M; Dräger, R.; Eibel, H.; Peter, H.H. (Freiburg)

Where Do Hematopoietic Stem Cells Come from?

Dieterlen-Lièvre, F,; Godin, I.; Pardanaud, L. (Nogent s/Marne)

Activation of Signaling Pathways and Prevention of Apoptosis by Cytokines in Eosinophils

Yousefi, S.; Blaser, K.; Simon, H.-U. (Davos)

Original Paper

100 Acknowledgment to Reviewers 35 Announcement

No. 2

13 Dexamethasone Suppressed Gene Expression and Production of lnterleukin-10 by Human Peripheral Blood Mononuclear Cells and Monocytes

Fushimí, T.; Okayama, H.; Seki, T.; Shimura, S.; Shirato, K. (Sendai)

19 Influence of Degraded Phosphatidylserine on Binding of Antiphospholipid Antibodies Boz $1 / 8$ B.; Kveder, T.; Stegnar, M.; Morosini-Berus, E.; Kos-Golja, M.; Peternel, P.; Rozman, B. (Ljubljana/Novo Mesto)

27 Role of Resident Mast Cells and Macrophages in the 
Neutrophil Migration Induced by LTB4, fMLP and C5a des arg

Ribeiro, R.A.; Souza-Filho, M.V.P.; Souza, M.H.L.P.; Oliveira, S.H.P.; Costa, C.H.S.; Cunha, F.Q.; Ferreira, S.H. (Fortaleza/Ribeirâo Preto)

36 Existence of c-kit Receptor-Positive, Tryptase-Negative, IgE-Negative Cells in Human

Allergic Nasal Mucosa: A Candidate for Mast Cell Progenitor

Kawabori, S.; Kanai, N.; Tosho, T.; Adachi, T. (Asahikawa)

44 Genomic Organization and Polymorphisms of the Major House Dust Mite Allergen Der f 2

Yuuki, T.; Okumura, Y.; Okudaira, H. (Tokyo) 49 Role of IL-13 in CD4 T Cell-Dependent IgE

Production in Atopy

Levy, F.; Kristofic, C; Heusser, C; Brinkmann, V. (Basel)

59 Relationship between Activated Eosinophils of the Bronchial Mucosa and Serum Eosinophil

Cationic Protein in Atopic Asthma

Hoshino, M.; Nakamura, Y. (Tokyo)

65 Differences in Nonspecific Bronchial Responsiveness between Patients with Asthma and

Patients with Rhinitis Are Not Explained by Type and Degree of Inhalant Allergy

Witteman, A.M.; Sjamsoedin, D.H.S.; Jansen, H.M.; van der Zee, J.S. (Amsterdam)

73 Dermatophagoides-farinae-|nduced Pulmonary Eosinophilic Inflammation in Mice

Yu, C.-K.; Yang, B.-C; Lee, S.-C; Wang, J.-Y.; Hsiue, T.-R.; Lei, H.-Y. (Tainan)

83 Adenosine Modulates Endothelin-lnduced Bronchoconstriction in Guinea Pig Airway

Kanazawa, H.; Fujiwara, H.; Shoji, S.; Fujii, T,; Kudoh, S,; Hirata, K.; Kurihara, N.; Yoshikawa,

J. (Osaka)

88 Responses of Monkeys with PoMinosis to Two Major Allergens of Japanese Cedar Pollen

Hashimoto, M,; Kobayashi, T.; Nigi, H.; Saito, S.; Nakayama, I.; Narita, T.; Iwata, M.; Yasueda, H.; Taniguchi, Y.; Kurimoto, M.; Inouye, S.; Sakaguchi, M. (Tokyo/Kanagawa/Okayama)

Review

103 Antigen Presentation of Mucosal Pathogens: The Players and the Rules

Reyes, V.E.; Ye, G.; Ogra, P.L.; Garofalo, R. (Galveston, Tex.)

Original Paper

115

Role of Hemolytic and Nonhemolytic Phospholipase C from Pseudomonas aeruginosa for Inflammatory Mediator Release from Human Granulocytes

König, B. (Bochum); Vasil, M.L. (Denver, Colo.); König, W. (Bochum)

Immunostimulatory Effects of Platinum Compounds: Correlation between Sensitizing Properties in vivo and Modulation of Receptor-Mediated Endocytosis in vitro

Schuppe, H.-C; Kulig, J. (Dusseldorf); Kühn, U.; Lempertz, U. (Mainz); Kind, P. (Munich);

Knop, J.; Becker, D. (Mainz)

Flow-Cytometric Analysis of T-Cell Receptor Expression in Peripheral Blood Lymphocytes

Liebers, V.; Raulf-Fteimsoth, M.; Krekel, C; Baur, X. (Bochum)

Detection and Characterisation of Anti-Endomysial Antibody in Coeliac Disease Using Human

Umbilical Cord

Yiannakou, J.Y.; DelГOlio, D.; Saaka, M.; Ellis, H.J. (London); Rosen-Bronson, S.

(Washington, D.C.); Dumonde, D.C.; Ciclitira, P.J. (London)

Differing Regulation of Major Histocompatibility Class II and Adhesion Molecules on Human

Umbilical Vein Endothelial Cells by Serotonin

Li, F.; Joshua, I.G.; Lian, R.; Justus, D.E. (Louisville, Ky.)

High Levels of Circulating lnterleukin-4 and lnterleukin-10 in Kawasaki Disease 
Hirao, J.; Hibi, S.; Andoh, T,; Ichimura, T. (Tochigi)

Inhibition of Neutrophil Elastase-lnduced lnterleukin-8 Gene Expression by Urinary Trypsin Inhibitor in Human Bronchial Epithelial Cells

Nakamura, H.; Abe, S.; Shibata, Y.; Sata, M.; Kato, S.; Saito, H.; Hino, T.; Takahashi, H.;

Tomoike, H. (Yamagata)

Combinations of IgE Values and Lymphocyte Proliferative Responses for Consideration of the

Clinical Course of Infantile Hen's-Egg-Sensitive Atopic Dermatitis

Shinoda, S.; Agata, H.; Fukutomi, O.; Kondo, N. (Gifu)

\section{KARGEK}

E-Mail karger@karger.ch Fax+4161 3061234 http://www.karger.ch

(C) 1997S. KargerAG, Basel

The list of contents is available at: http://www.karger.ch/journals/iaa/iaacont.htm

169 Characterization of Aedes communis, Aedes aegypti and Anopheles Stephens'! Mosquito

Saliva Antigens by Immunoblotting

Brummer-Korvenkontio, H.; Palosuo, T. (Helsinki); Francois, G. (Antwerp); Reunala, T.

(Helsinki)

175 Total and Birch Pollen-Specific Human IgE in Mice with Severe Combined

Immunodeficiency Transplanted with Human Peripheral Blood Lymphocytes: Donor

Dependence, Seasonal Variation and in vivo Half-Life

Steinsvik, T.E.; Aaberge, I.S.; Gaarder, P.I.; Bjønness, U.; Løvik, M. (Oslo)

184 Grass Immunotherapy Induces Inhibition of Allergen-Specific Human Peripheral Blood

Mononuclear Cell Proliferation

Baskar, S.; Hamilton, R.G.; Norman, P.S.; Ansari, A.A. (Baltimore, Md.)

191 Interaction of Ozone and Allergen Challenges on Bronchial Responsiveness and

Inflammation in Sensitised Guinea Pigs

Sun, J.; Koto, H.; Chung, K.F. (London)

196 Effect of Maturation on Allergen-Induced Airflow Obstruction and Airway Plasma

Exudation in Sensitized Guinea Pigs

Arakawa, H.; Tokuyama, K.; Mochizuki, H.; Morikawa, A. (Maebashi); Lötvall, J. (Gothenburg)

132 Announcement

270 Role of Particulate Antigens of Aspergillus in Murine Eosinophilia

Kurup, V.P.; Choi, H.; Murali, P.S.; Resnick, A.; Fink, J.N. (Milwaukee, Wise.); Coffman, R.L. (Palo Alto, Calif.)

279 Development of Antigen-Specific IgE after Sensitisation with Trimellitic Anhydride in Rats Is Attenuated by Glucocorticoids and Cyclosporin A

Pullerits, T.; Dah¹/8ren, U.; Skoogh, B.-E.; Lötvall, J. (Gothenburg)

287 A Monoclonal Antibody against Very Late Activation Antigen-4 Inhibits Eosinophil

Accumulation and Late Asthmatic Response in a Guinea Pig Model of Asthma

Sagara, H.; Matsuda, H.; Wada, N.; Yagita, H.; Fukuda, T.; Okumura, K.; Makino, S.; Ra, C.

(Tokyo)

295 Mite-Induced Allergic Airway Inflammation in Guinea Pigs

Hsiue, T.-R.; Lei, H.-Y.; Hsieh, A.-L.; Wang, T.-Y.; Chang, H.-Y.; Chen, C.-R. (Tainan)

303 Evidence That Allergen-Induced Contraction of Guinea Pig Bronchi Is Mediated in Part by the Release of Tachykinins 
Kohrogi, H.; Yamaguchi, T.; Iwagoe, H,; Fujii, K.; Hamamoto, J.; Kawano, O.; Ando, M.

(Kumamoto)

Short Communications

No. 3

Review

203 Melatonin and the Immune System

Liebmann, P.M.; Wölfler, A.; Felsner, P.; Hofer, D.; Schauenstein, K. (Graz)

Original Paper

212 In vitro Lymphocyte Proliferation as Compared to Patch Test Using Gold, Palladium and

Nickel

Cederbrant, K.; Hultman, P. (Linköping); Marcusson, J.A. (Huddinge); Tibbling, L. (Linköping)

218 Immunological and Biological Properties of Recombinant Lolpl

Boutin, Y.; Lamontagne, P.; Boulanger, J.; Brunet, C; Hébert, J. (Sainte-Foy)

226 The Murine (H-2k) T-Cell Epitopes of Bee Venom Phospholipase A2 Lie Outside the Active

Site of the Enzyme

Implications with Respect to a Paracrine Activation of Th2 Cells for an IgE Antibody Response

Specht, C; Kölsch, E. (Münster)

231 Cow Hair Allergen (Bos d 2) Content in House Dust: Correlation with Sensitization in

Farmers with Cow Hair Asthma

Hinze, S.; Bergmann, K.-C. (Bad Lippspringe); Løwenstein, H.; Hansen, G.N. (Hørsholm)

238 Efficacy Trial of Bioresonance in Children with Atopic Dermatitis

Schöni, M.H.; Nikolaizik, W.H.; Schöni-Affolter, F. (Davos)

247 Allergen-Specific Conjunctival Challenge in Asthma

An Additional Diagnostic Tool to Define Sensitization

Ciprandi, G,; Buscaglia, S.; Scordamaglia, A.; Canonica, G.W. (Genoa)

251 The Renin-Angiotensin System in Patients with Repeated Anaphylactic Reactions during

Hymenoptera Venom Hyposensitization and Sting Challenge

Hermann, K,; Ring, J. (Munich)

$257 \mathrm{C} / \mathrm{s}$-Urocanic-Acid-Induced Suppression of Contact

Hypersensitivity in Monodelphis domestica Is Prevented by Ultraviolet A

Radiation/Photoreactivating Light

Reeve, V.E. (Sydney); Ley, R.D. (Albuquerque, N. Mex.)

262 The Role of Neutrophil Elastase in Human Pulmonary Artery Endothelial Cell Injury

Furuno, T.; Mitsuyama, T.; Hidaka, K.; Tanaka, T.; Hara, N. (Fukuoka)

309 Correlation between Bronchoalveolar Lavage (BAD Fluid Cell Lysate Histamine Content

and BAL Fluid Eosinophil Count in Atopic and Nonatopic Asthmatics

Louis, R.; Van Tulder, L.; Poncelet, M.; Corhay, J.L.; Mendez, P.; Radermecker, M. (Liege)

313 IgE Antibody Response against Aspergillus umbrosus in Farmer's Lung Disease

Kaukonen, K.; Savolainen, J.; Nermes, M.; Viander, M.; Terho, E.O. (Turku)

286 Addendum

No. 4

Mini Review

317 Dendritic Cells: From Ignored Cells to Major Players in T-Cell-Mediated Immunity

Schuler, G; Thurner, B. (Erlangen); Romani, N. (Innsbruck)

Original Paper 
323 Cytokine Production in Response to Stimulation with Tetanus Toxoid, Mycobacterium tuberculosis and Influenza Antigens in Peripheral Blood Mononuclear Cells and T Cell Lines from Healthy Elderlies

Bodnár, Z. (Innsbruck/Debrecen); Steger, M.M.; Saurwein-Teissl, M.; Maczek, C; GrubeckLoebenstein, B. (Innsbruck)

331 Association of Natural Killer Cell Activity with Serum IgE

Kusaka, Y.; Sato, K.; Zhang, Q.; Morita, A. (Fukui); Kasahara, T. (Tokyo); Yanagihara, Y. (Kanagawa)

336 Patch-Clamp Characterization of Secretory Process in Human Basophils

Oshiro, T.; Kakuta, Y.; Maruyama, N.; Fushimi, T.; Okayama, H.; Tamura, G; Shimura, S.; Shirato, K. (Sendai)

341 Cloning and IgE Binding of a Recombinant Allergen from the Mite Blomia tropicalis, Homologous with Fatty Acid-Binding Proteins

Caraballo, L.; Puerta, L.; Jimenez, S.; Martinez, B.; Mercado, D. (Cartagena); Avjiouglu, A.; Marsh, D. (Baltimore, Md.)

348 Isolation and Characterization of Two cDNA Clones Coding for Isoforms of the Parietaria judaica Major Allergen Par j 1.0101

Duro, G; Colombo, P.; Costa, M.A.; Izzo, V.; Porcasi, R.; Di Fiore, R.; Locorotondo, G.;

Cocchiara, R.; Geraci, D. (Palermo)

Contents

Int Arch Allergy Immunol Vol. 112, 1997

III

356 Mercurialis annua: Characterization of Main Allergens and Cross-Reactivity with Other Species

Vallverdú, A. (Bilbao); García-Ortega, P. (Tarragona); Martinez, J.; Martinez, A. (Bilbao);

Esteban, M.I. (Segovia); de Molina, M. (Llobregat); Fernández-Távora, L. (Huelva); Fernandez, J. (Elche); Bartolomé, B.; Palacíos, R. (Bilbao)

365 Dermatophagoides farinae- $\Lambda$-Derived Peptides and HLA Molecules Recognized by T Cells from Atopic Individuals

Matsuoka, T.; Kohrogi, H.; Ando, M.; Nishimura, Y.; Matsushita, S. (Kumamoto)

371 The 'Travelling Salesman Problem': A New Approach for Identification of Differences among Pollen Allergens

Kosman, E.; Eshel, A.; Waisel, Y. (Tel Aviv)

378 Differentiation between Cosensitization and Cross-Reactivity in Wheat Flour and Grass Pollen-Sensitized Subjects

Sander, I.; Raulf-Heimsoth, M.; Düser, M.; Flagge, A.; Czuppon, A.B.; Baur, X. (Bochum)

386 Circulating Intracellular Adhesion Molecule-1 Concentrations following Bronchial

Provocation in Atopic Asthma

Gonokami, Y.; Konno, S.; Kurokawa, M.; Kawazu, K.; Ueno, K.; Tomita, K.; Ike, M.; Nyui, M.;

Adachi, M. (Tokyo)

392 Effects of Phosphatidylinositol-3-Kinase Inhibitors on

Degranulation and Gene Induction in Allergically Triggered Mouse Mast Cells

Pendl, G.G.; Prieschl, E.E.; Thumb, W.; Harrer, N.E.; Auer, M.; Baumruker, T. (Vienna)

400 Involvement of Thromboxane A2 in Antigen-Induced Nasal Blockage in Guinea Pigs

Yasui, K.; Asanuma, F.; Fume, Y.; Arimura, A. (Osaka) 
406 Effect of T-440, a Novel Type IV Phosphodiesterase Inhibitor, on Allergen-Induced Immediate and Late Asthmatic Reaction and Leukocyte Infiltration into the Airways of Guinea Pigs

Kaminuma, O.; Kikkawa, H.; Matsubara, S.; Ikezawa, K. (Saitama)

Short Communication

412 Immunological Cross-Reactivity of the Major Allergen from Perennial Ryegrass (Lolium perennel, Lolp I, and the Cysteine Proteinase, Bromelain

Pike, R.N.; Bagarozzi, Jr., D.; Travis, J. (Athens, Ga.)

Case Reports

415 IgE Lambda Monoclonal Gammopathy and Amyloidosis

Jákó, J.M. (Budapest); Gesztesi, T. (Szekszàrd); Kaszás, I. (Budapest) 422 Extremely High

Serum Level of IgE during

Immunosuppressive Therapy: Paradoxical Effect of $\mathrm{C} \gamma \mathrm{closporine} \mathrm{A}$ and Tacrolimus

Kawamura, N,; Furuta, H.; Tame, A.; Kobayashi, I.; Ariga, T.; Okano, M.: Sakiyama, Y.

(Sapporo)

385 Announcement

425 Author Index Vol. 112,1997

427 Subject Index Vol. 112,1997

\section{KARGER}

\section{S. Karger}

Medical and Scientific Publishers Basel · Freiburg · Paris a London New York · New Delhi ·

Bangkok Singapore $\cdot$ Tokyo $\cdot$ Sydney

Drug Dosage

The authors and the publisher have exerted every effort to ensure that drug selection and dosage set forth in this text are in accord with current recommendations and practice at the time of publication. However, in view of ongoing research, changes in government regulations, and the constant flow of information relating to drug therapy and drug reactions, the reader is urged to check the package insert for each drug for any change in indications and dosage and for added warnings and precautions. This is particularly important when the recommended agent is a new and/or infrequently employed drug.

All rights reserved.

No part of this publication may be translated into other languages, reproduced or utilized in any form or by any means, electronic or mechanical, including photocopying, recording, microcopying, or by any information storage and retrieval system, without permission in writing from the publisher or, in the case of photocopying, direct payment of a specified fee to the Copyright Clearance Center (see 'Information for Readers and Subscribers').

(C) Copyright 1997 by S. Karger AG, P.O. Box, CH-4009 Basel (Switzerland) Printed in Switzerland on acid-free paper by Reinhardt Druck, Basel

IV

Int Arch Allergy Immunol Vol. 112, 1997

Contents 